\title{
De Gentse veemarkt en het stedelijk slachthuis tijdens WO II
}

\author{
Anonieme tekst \\ Schenking Marcel Vanderstraeten, DSMG Documentatiecentrum voor Streekgeschiedenis, \\ Begijnhof 46, 9040 Sint-Amandsberg. \\ Bewerking naar hedendaags taalgebruik: Luc Devriese
}

\section{SLACHTHUIS EN OMGEVING}

Naast een bewaard gebleven vleugel van het oude slachthuis, nog gebouwd naar uitgediende opvattingen, verrijzen nu de ultramoderne inrichtingen ontworpen volgens de nieuwste bouwtechnieken met goed verlichte en verluchte lokalen, burelen, inspectie- en controle-afdelingen, weegtoezicht, gezondheids- en reinigingsdiensten. Het zijn deze perfecte installaties die het Gentse slachthuis toelaten ten volle aan zijn bestemming te beantwoorden.

Vooraan ligt een vierkante blok grond met smalle rode tegeltjes geplaveid en verdeeld in vakken die door smalle gangetjes van elkaar gescheiden zijn. Over het geheel van de gebouwen, in kruisvorm door bredere toegangen in vier grote afdelingen verdeeld, werden stalen gebinten gespannen. Ze rusten op ijzeren en betonnen pijlers die de golvende eternietbedekking (golfplaten) schragen. Onder deze ruimten hebben wind en storm vrij spel, maar mens en dier worden beschut voor regen en sneeuwval. De constructie laat de doordringende kilte van nattigheid niet binnen.

In de wijk staat bijna alles in functie van vee en vlees. Enkele namen van omliggende straten spreken

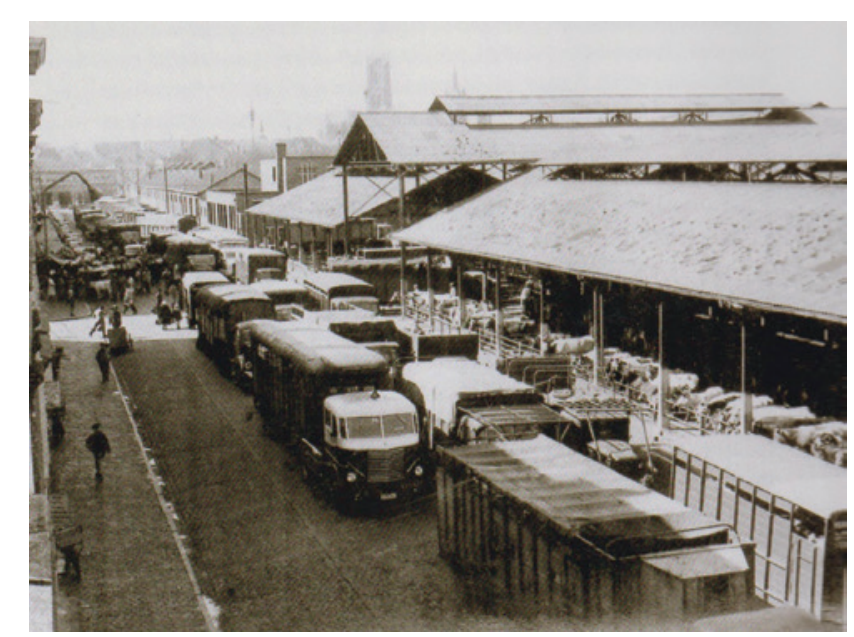

Het nieuwe slachthuis (in de jaren 1940) op een marktdag met talrijke veewagens in de Slachthuisstraat. Bemerk de middenpartij met grote open toegang. Overgenomen uit Audooren, F. (red., 2015). Het Slachthuis verteld/t (Stad Gent).

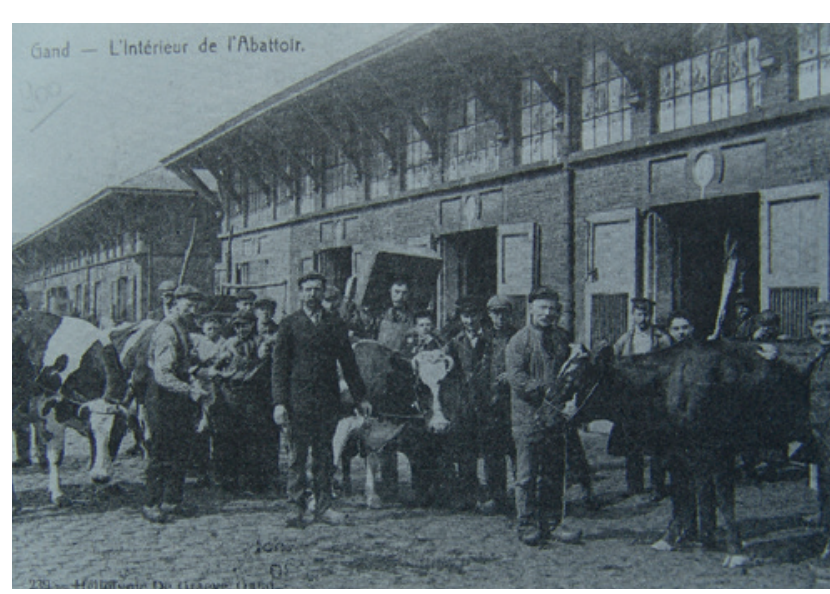

Een gedeelte van het eerste slachthuis in 1858 gebouwd naar ontwerp van stadsarchitect Louis Roelant (ongedateerde foto genomen op de binnenkoer. Verzameling E. Levis).

voor zich: de Ossen- en Schaapstraat (nu Ooilamstraat), de Paardestraat, de Slachthuisstraat. In de onmiddellijke omgeving herkent men handelszaken die er mee te maken hebben: een ijsfabriek, koelkamers, winkels voor slagersbenodigdheden. Allen bedrijven die uitsluitend aangewezen zijn op het bestaan van de veemarkt en het slachthuis. Daar zijn zaken te krijgen, die men elders tevergeefs zal zoeken. De marktdieren, die de dag voordien of tijdens de nacht aangevoerd werden, kunnen er korte tijd gestald worden.

\section{MARKT VOOR LEVEND VEE}

Onze hoofdbedoeling is een beeld te schetsen van het wereldje dat op de veemarkt te zien en te horen was: de boer en veekoopman als verkopers, de groothandelaar als koper, het slachthuis als verwerker, en tenslotte de beenhouwer als laatste tussenpersoon.

Het dier is het voorwerp (sic: zo staat het er!) dat, met tram, trein of vrachtwagen vervoerd, soms ook na een lange voetreis hier belandt. Van daags tevoren of 's morgens in 't halfduister kunt ge 't aan de leiband zien opstappen. Het schijnt vermoeid. We zagen het al door de getraliede opening van de goederenwagens, 


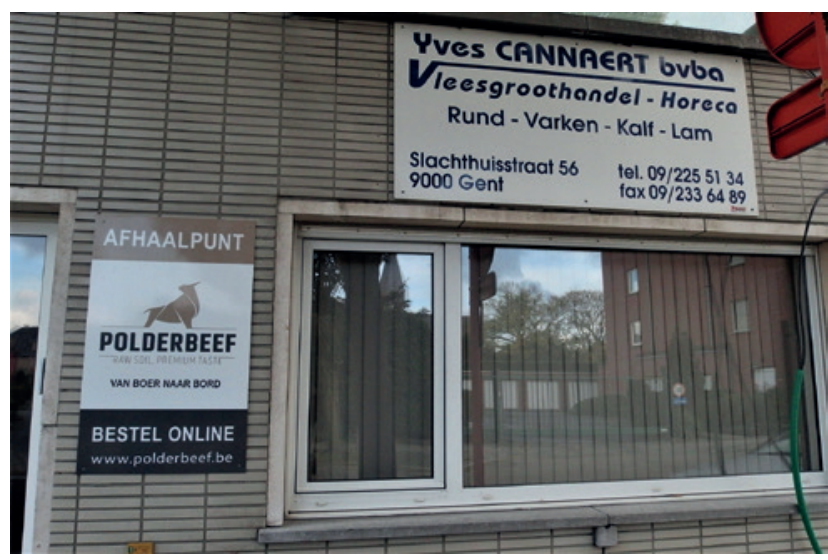

Een enkele overgebleven vleesgroothandel in de Slachthuisstraat, met een hedendaagse toets (Foto: 2021).

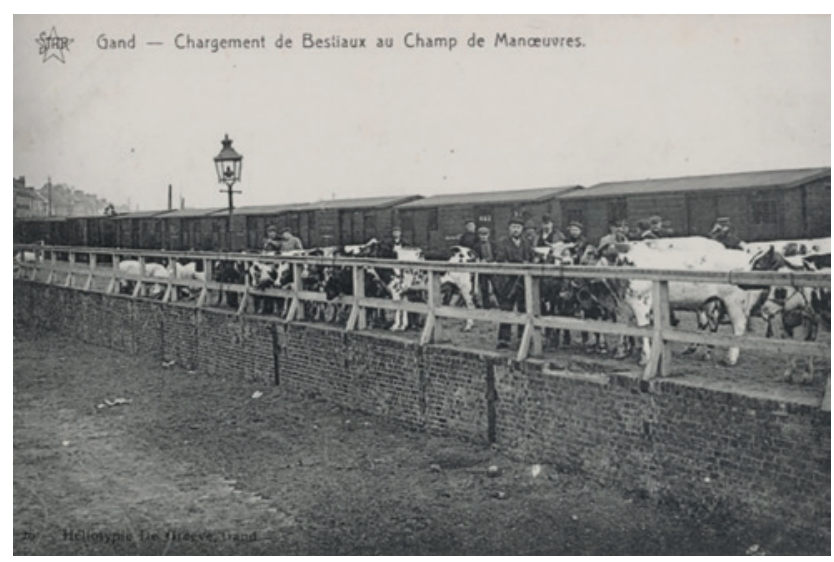

Voor er 'automobiele' camions beschikbaar waren, werd heel wat vee vervoerd per trein. Het huidige grote parkeerterrein aan het Dampoortstation werd ingericht op een vroeger oefenplein (champ de manoeuvres) van de Burgerwacht, dat nadien dienst deed als laad- en losruimte voor onder andere rundvee (Foto uit privébezit).

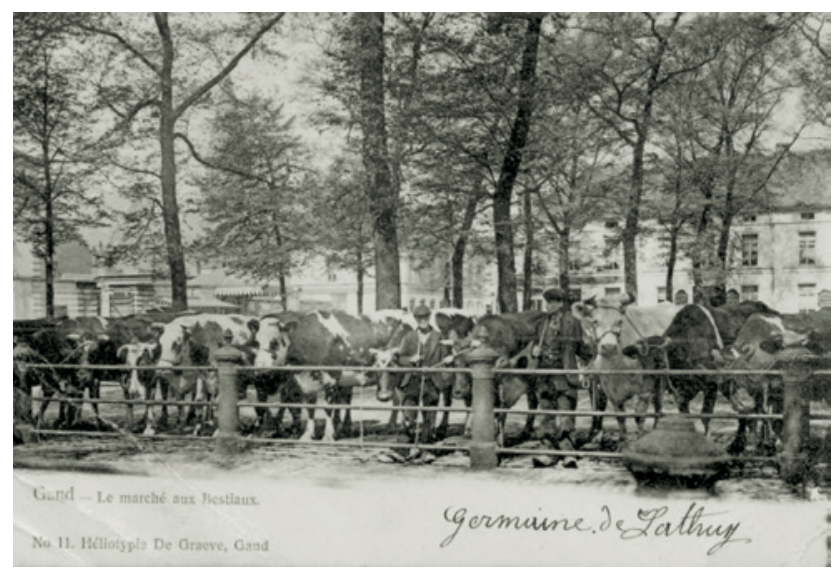

De Gentse nieuwe beestenmarkt tussen de Slachthuisen de Gandastraat. Bemerk de zeer kloeke 'baalden' (baliepalen) (Foto uit privébezit). loeiend van honger en likkend aan het ijzeren belegsel. Hoelang is het reeds op weg? Het schijnt tevreden, want het verging zo dikwijls goed wanneer het van een corvee, zoals monstering en keuring, naar zijn stal mocht terugkeren. Dan was het kermis in de voederkribbe.

$\mathrm{Nu}$ zal men de dieren vastbinden aan lange ijzeren staven, die aan stevige palen met dikke schroeven zijn bevestigd. Er zijn er honderden, het ene dier nevens het ander. Ze zijn vastgesnoerd met korte strengen en raken met de kop aan de 'baalden' (balies, palen). Ze kunnen zich moeilijk bewegen, alleen het achterlijf is vrij. Soms trekken ze wild aan dat bindsel en stoten met hun lijven woest tegen elkaar. Prijsbeesten nevens gemeen slachtvee, schapen en zwijns, ' $t$ kreeg elk een plaatske. Zie me daar een luie os, die met zijn logge gedaante stokstil en onverschillig op die vreemde wereld toekijkt. En die wilde stier met een koord door zijn neusring door een koeier in bedwang gehouden. Zijn geloei overstemt de markt, de spieren zijn als vuisten gebald, de staart slaat woest in het rond als een pezige zweep. Men moest hem blinddoeken: het schuim vlokt aan zijn muil.

Een domme 'mutte' schijnt zich af te vragen waar het met de beestenwereld naartoe gaat. En dan die kalveren: wat een povere vertegenwoordigers van onze schone veestapel. Dat is weerspannig, altijd verkeerd doend, voor geen rede vatbaar, dol springend op de hoge, te grove poten: een pest voor leider en drijver. Nu eens voorthollend, de hele straat belemmerend, als een tol draaiend en kerend om dan weer stil te staan en met onverzettelijke koppigheid, de achterpoten naar buiten, in de straatvoegsels plantend; tot men zich verplicht ziet het dier met drie of vier man op te pakken en het binnen de omheining van een veebascule te duwen.

De zwijnen zijn al even onhandelbaar. Raakt ge hun vel aan of strijkt ge eventjes over kop en oren, ge zult ze meteen horen protesteren. Hun geknor kan uitgroeien tot een vervaarlijk geschreeuw dat de hele buurt in rep en roer zet. Deze logge vetbeesten leven slechts om te eten of te slapen. Het marktrumoer is niet naar hun zin, noodgedwongen moet men ze aan de oren voortslepen terwijl een sterke slager door fors te heffen aan het staartje, de poten onder het 'achterkasteel' tot de zonderlingste sprongen weet te bewegen. De kleinen zijn evengoed roerme-nietjes. Tilt men ze uit hun manden, dan roepen ze moord en brand. En opgelet dat ge ze niet meer loslaat: in een oogwenk wippen ze tussen je broekspijpen weg en 't zal een heel tijdje duren vooraleer ze weer worden gevangen.

Zacht en gedwee zijn schapen en lammeren. Vooraan aan de ingang van het slachthuis wachten ze hun beurt af. Je leest meewarigheid in die ogen, berusting hen zich gewillig schikken doet naar het 


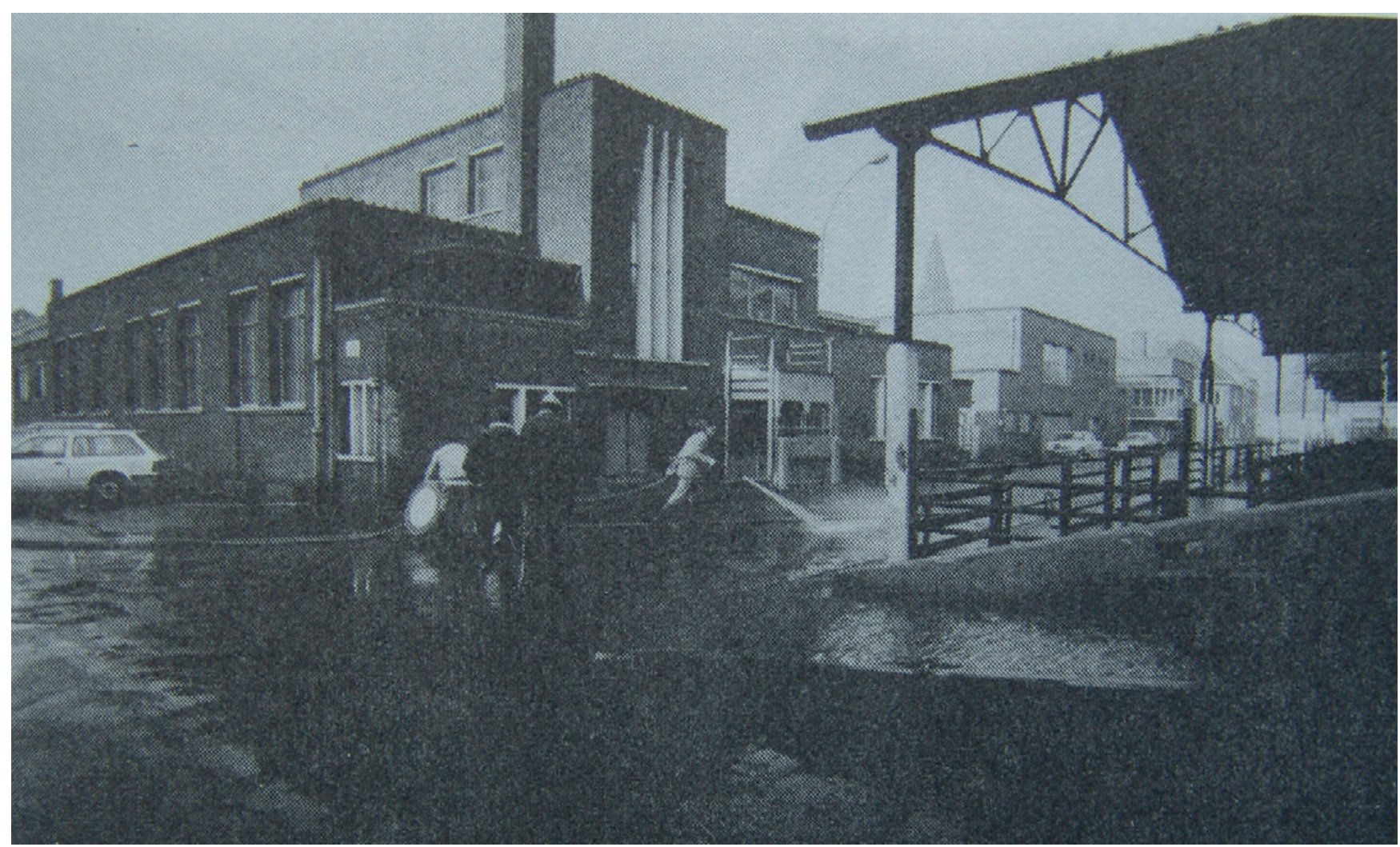

Na de markt: het vuil wordt weggespoten. Het verdwijnt in de riool om enkele tientallen meter verder ongezuiverd in het Visserijkanaal te belanden (Foto: Michel Hendryckx). De Aquafinwerken, die dergelijk afvalwater naar het waterzuiveringsstation in de Ossemeersen (Bourgoyen) moesten voeren, startten in deze zone net op het moment dat het slachthuis sloot. De gebouwen links boden onderdak aan kantoren, een laboratorium en een leszaaltje.

onverbiddelijke lot dat hen weldra wacht. Men zegt dat schapen wenen, ik heb het nog niet gezien.

\section{SLACHTEN}

Een na een moeten ze de doodsformaliteiten van de stadsweger ondergaan. Daarna verdwijnen ze achter de poort, waar hen onherroepelijk de dood wacht. Te

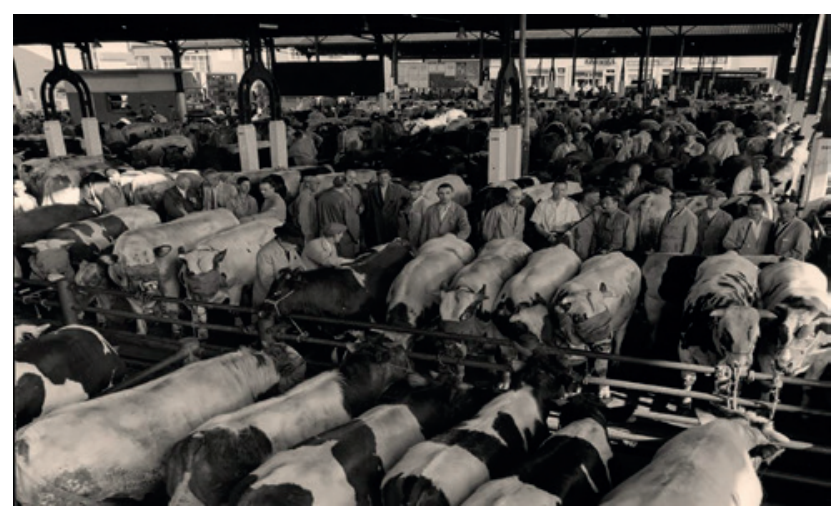

Een heel drukke markt, wellicht op een prijskampdag. Misschien van de 'Vette Os', het jaarlijkse evenement ingericht door de toen florerende slagersvereniging 'De Breidelzonen'? (Foto uit privébezit). midden der onbewuste levenskracht die uit de mengeling van dierenklanken oplaait, beweegt zich de mens. Hij is hier heer en gebieder. Zijn scepter is een stok, zijn harnas is de lange blauwe schort die zijn kleren van bevuiling moet vrijwaren. Aan zijn hoede werden deze redeloze wezens toevertrouwd. Hij zal ze geleiden, overleveren aan de slachters, daarna loon voor werk en moeite ontvangen.

Intussen wordt het ene dier na het andere geslacht. Geheel pijnloos met een eenvoudig slachtpistoolschot wordt een metalen pin in de hersenpan gedreven. De poten slaan onder het lijf weg en stuiptrekkend stort het dier ineen. De wetenschap heeft hun lijden uitgeschakeld. Hoogstens enkele zenuwschokken volgen. De grote slagaders bij het hart worden met een mes doorgestoken. Met het uitvloeien van het bloed verliezen de stuiptrekkingen aan kracht. De ogen breken, enige trillingen en ge bespeurt geen leven meer.

$\mathrm{Nu}$ mag men met het villen beginnen. We zullen niet verder uitweiden over de moderne werkwijze, noch de weg volgen die de geslachte dieren langs kabels automatisch afvoert om in de keuringsplaatsen te worden opgehangen. Zeggen we alleen dat het administratief werk hier zijn laatste beslag krijgt en andere diensten het nodige doen. 


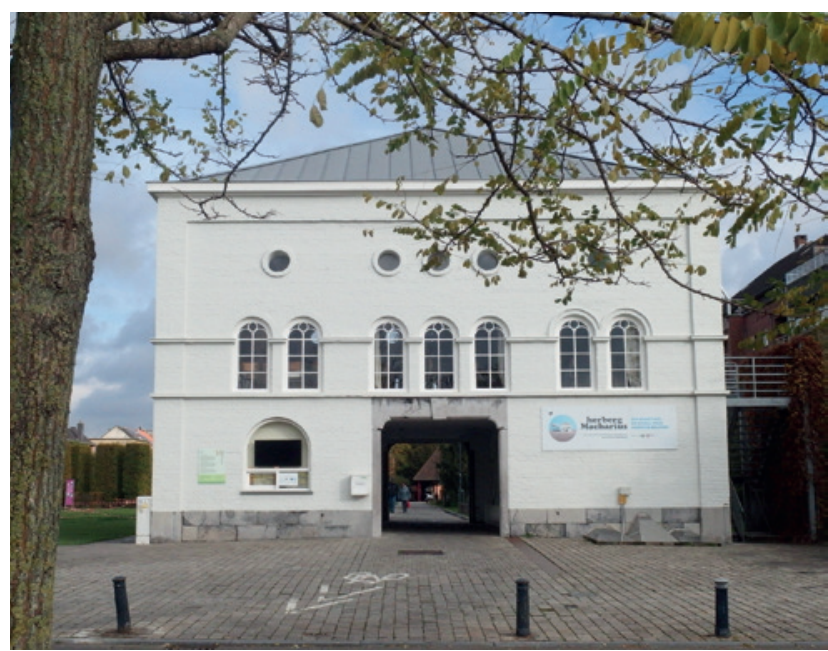

Het enige slachthuisgebouw dat bewaard bleef na de sluiting in 1986: de toegang aan de Voorhoutkaai. Nu 'Herberg Macharius' en hoofdkwartier van de wijkvereniging 'Buren van de Abdij' (Foto: 2021).

\section{EEN SFEERBEELD OP DE MARKT}

Breng nooit op een zondag een bezoek aan de nieuwe Veemarkt. Het zou U kunnen teleurstellen als je voor de gesloten portaaldeuren en neergelaten vensterblinden zou komen te staan. Verlaten is het er, geen levende ziel, tenzij een vrome kerkganger die zich hier haastig voorbij spoedt, en een paar honden die langs de muren lopen te snuffelen. Maar wanneer de wijk feest viert, vreugdemuziek door het gebuurte weergalmt en duizenden lichtjes de pleinen en huizen met een feeërieke gloed verlichten, dan is er veel volk. Maar dat is nog geen marktdag, geen heksenketel zoals bij de grote 'vergadering' van de dieren.

Komt, wanneer ge van verre die onbestemde klanken hoort van opgejaagde dieren en het geraden is het voetpad te gebruiken om aan het geweld van een opgejaagde kudde te ontsnappen. Komt dan om dat roekeloos spel te zien van onvervaarde mensen te midden van woelig en angstig vee.

En toch vinden de drijvers dat alles natuurlijk. Ze zwaaien hun knotsen en bedwingen de onstuimige instincten, al is het wel al gebeurd dat ze zwichten moesten voor aanvallen van dolheid en razernij. Dan komt het onbeteugeld beest opzetten en verplettert het de vermetele die het aandurven zou hem de pas af te snijden. De mensen vluchten de huizen in totdat een goed gemikt schot een einde komt stellen aan de beroering. Degenen die daarmee door hun dagelijkse omgang met vee vertrouwd zijn, kennen de gevaren van zo'n plotselinge verbijstering. Derhalve nemen ze steeds maatregelen die hen daartegen kunnen beveiligen.

\section{DE VEEKOOPMAN}

De veekoopman is hier duidelijk het hoofdpersonage. Hij is man met de wijde kiel en de drijfstok in de hand. Stel u geen luidruchtige vent voor die met een overvloed van woorden en een ongewone luidruchtigheid zijn beesten zoekt aan de man te brengen. Ge zijt mis: zakelijkheid, overtuigingskracht en kennis kenmerken. Hij looft en biedt, hemelt op wat hij niet nodig heeft, kent de gebreken van wat hij aanschaffen wil, somt de voordelen die de boer moeten overtuigen afnemer te worden van wat hij zelf tracht te verkopen. De handslag bekroont altijd een gedane zaak. Het 'sans gêne' dat hem kenmerkt, de knepen die hij gebruikt, doen niets af van zijn eerlijkheid. Hij zal bijvoorbeeld weten dat er op de hofstede een stal vol vette zwijnen zit, wel, hij vraagt naar een rund en laat de pachter zelf uit zijn schelp komen. In de regel is hij solidair met zijn collega's. Het komt eropaan door stille overeenkomsten op de 'stege' (moeilijk te overtuigen) pachthoeven een slag te doen ...

Zijn rijk gevulde geldtas schept altijd het nodige vertrouwen. Slagers, knechten en drijvers mogen een pintje meedrinken en voor een boer is hij nooit gierig. Hij zal met hen de markt afdrentelen, ge ziet ze tezamen aan de toonbank in het café. Dobbelspel en een rondedans worden niet gesmaad. De vriendschap wordt altijd overgoten. Dat ze al eens van de rechte baan afwijken is een spijtig gevolge van de verleiding die achter hoeken en kanten schuilt. Dat ze al eens toegeven aan het verlokkend geldspelen met 'ankers en zonnen', het hoort helaas bij de schaduwzijden die de geldhonger uitdagen. 't Begint zo vaak

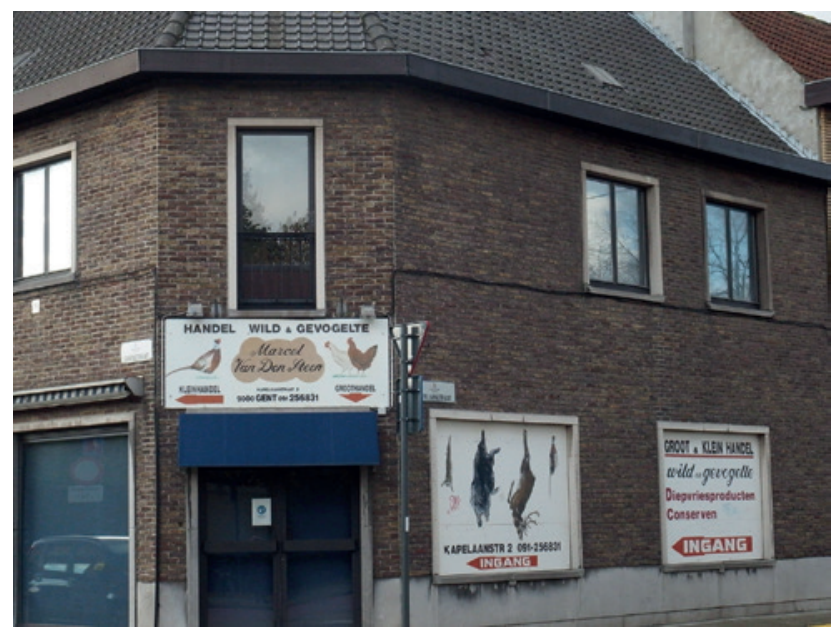

Zonder rechtstreeks verband met het slachthuis en de veemarkt (verhuisd naar Brugge in 1991), maar in dezelfde sector actief, vlakbij ingericht en gebleven: een poeljeniershandel (wild en gevogelte). Links: de Gandastraat, adres van het vroegere slachthuis; rechts: de Kapelaanstraat (Foto: 2021). 


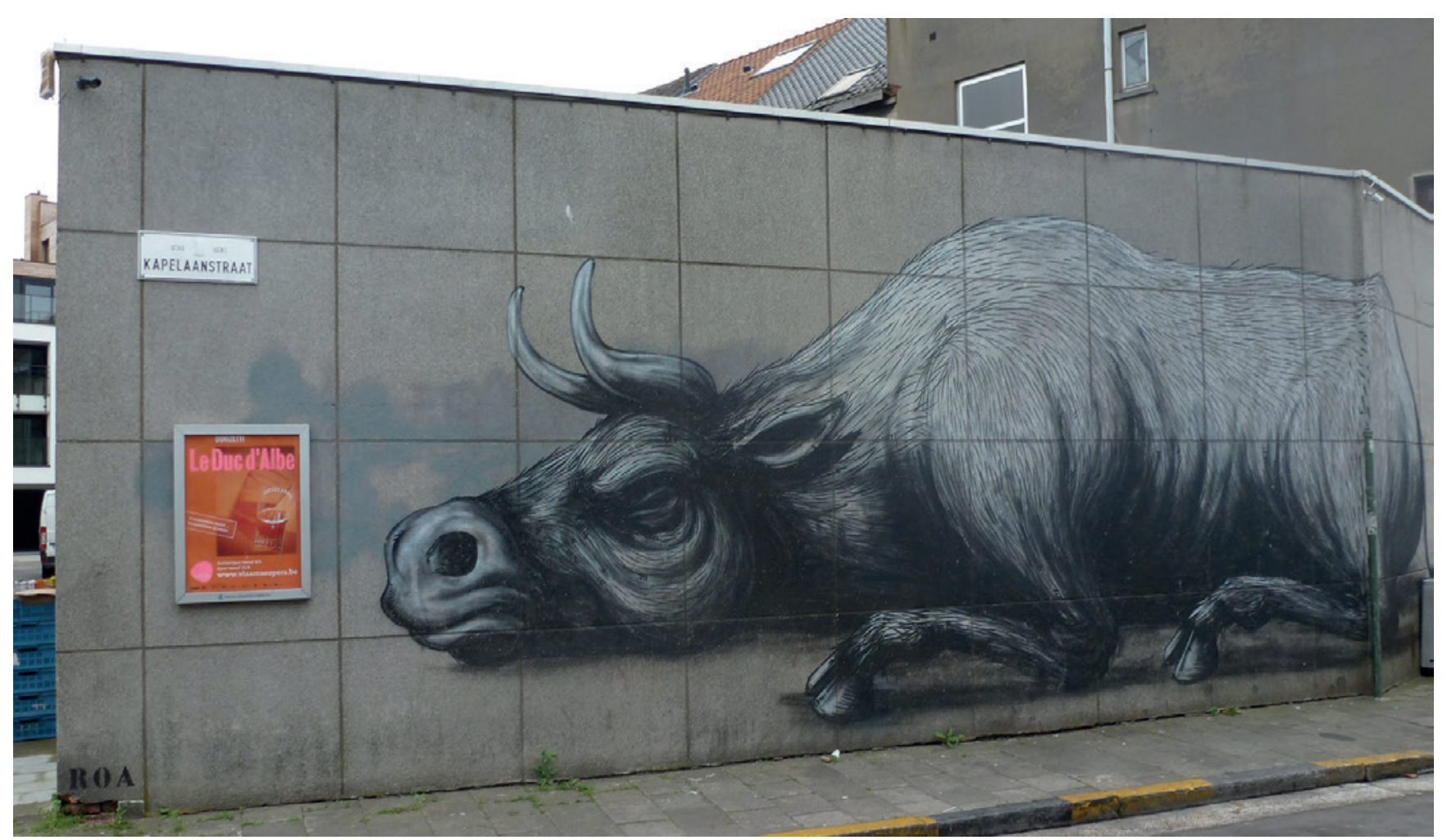

Een meesterlijk stukje straatkunst ('street art' in het jargon), onmiskenbaar van ROA (Foto: 2012). Dit sneuvelde bij werken aan de straat. Anno 2021 blijft er enkel nog een klein stukje bewaard (op de foto uiterst rechts, voorbij de hoek).

met een klein briefje om te eindigen met een resem banknoten. Hoevelen hebben hier in enkele minuten een rund of koe verspeeld? Overhitte zenuwen, verdronken verstand zijn factoren die elke notie van waarden doen verliezen.

De veemarktdag zoals hij in deze oorlogsdagen aan de strenge reglementering van de leveringsverplichtingen is onderworpen, gebonden aan een reeks formaliteiten, zal eerst zijn waarachtig karakter terugvinden wanneer de verhandelingen vrij zullen mogen geschieden zoals voor de oorlog. Het moet weer tot de vrije ruiling komen, tot de onbelemmerde uitwisseling: het geordend zakenleven tussen koopman, boer en beenhouwer. Dan zullen veel incidenten worden voorkomen, veel beroepsnijd en misnoegdheid worden uitgewist, in het besef dat alleen welstand heersen kan waar eerlijke mededinging de vlag hooghoudt. We vonden hier zoveel dat de mensen typeerde in omgang, verkoopwijze, zelfzekerheid, vrijpostig optreden...

\section{DE MARKT IS VOORBIJ}

Nieuwe drukte heerst op de markt. De straatvegers zijn gekomen en laden hun stootkarren vol. Men spuit de vuiligheid in de riolen. Er hangt een stalreuk over het wijde plein en het ruikt er naar creoline. De dieren zijn naar hun bestemming verwezen. Au- to's toeteren weg. Er kleeft nog bloed aan de schorten en zweet parelt op de voorhoofden.

Het doek valt andermaal. De markt is leeggelopen, de huizen vol... Goochelaars treden op, krachtpatsers plooien dikke ijzerstaven in hun nek of breken metalen geldstukken tussen de vingers. Kalaber (zoethout) spekken worden door een neger aangeboden. Behendige trucjes kloppen het geld uit de zakken van koopman en boer. Die verstaan de 'toverij' niet. Oude vrouwen bedelen om aalmoezen, kinderen schooien. De boerderij, het verre bedrijf wordt in deze ogenblikken vergeten. Een sukkelaar speelt harmonica. Hij is vergezeld van een zwart meisje. Men giechelt aan de toog. Ruwe handen knijpen in de arm van ongegeneerde diensters, de wijzers staan niet stil. Het zal nog lang duren vooraleer de orgelpijpen zullen zwijgen en het geroezemoes zal verstommen in de stille en late uren van de nacht.

\section{NAWOORD (Luc Devriese)}

$\mathrm{Nu}$ is dat bijna allemaal lang geleden verdwenen. Het Gentse slachthuis sloot in 1986. De veemarkt, of wat er nog van overbleef, verhuisde in 1991 naar Brugge. Te grote investeringen zouden nodig geweest zijn om de instelling aan te passen aan de Europese richtlijnen. Een inplanting midden de stedelij- 
ke bebouwing was trouwens niet meer verantwoord.

Enkele herinneringen blijven anno 2021 nog zichtbaar in het straatbeeld: de toegang van het negentiende-eeuwse slachthuis, een enkele vleesgroothandel in de Slachthuisstraat, een vleeshandel zonder rechtstreeks verband met het slachthuis, en ... tot voor enkele jaren kon je er een indrukwekkend stukje straatkunst, getekend ROA, bewonderen.

Inhoudelijk ongewijzigd. Met dank aan Adrien Brysse voor het toegankelijk maken van tekst en foto's.
Een boek over de geschiedenis van het Gentse slachthuis en de veemarkt 'Het slachthuis verteld/t' is verkrijgbaar bij 'De Buren van de Abdij', die tijdens het goeie seizoen op zondagen in de opengestelde abdijuïnes en de herberg Macharius in het poortgebouw openhouden. Een aanrader.

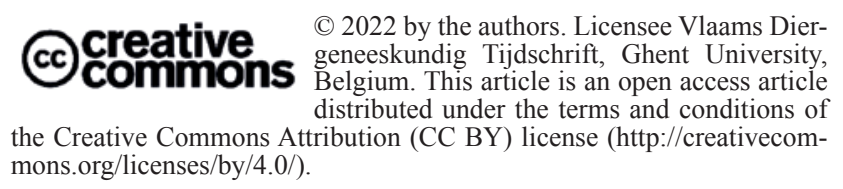

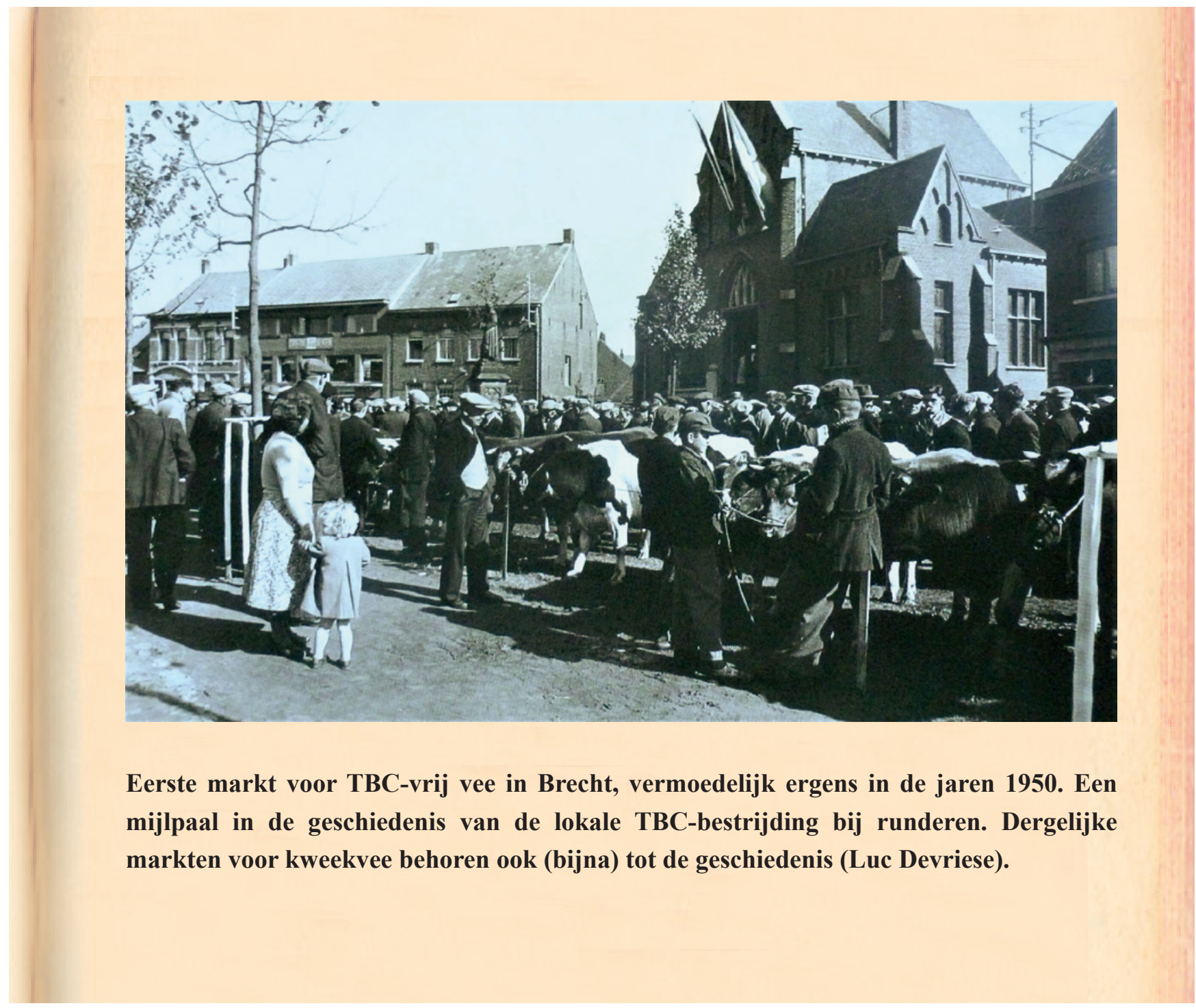

